\title{
The Customers' Brand Identification with Luxury Hotels: A Social Identity Perspective
}

\author{
By R.A. Rather ${ }^{1}$, University of Jammu, Jammu and Kashmir, INDIA, and \\ Mark Anthony Camilleri², University of Malta, MALTA and University of Edinburgh, \\ SCOTLAND.
}

This is a pre-publication version.

How to Cite: Rather, R.A. \& Camilleri, M.A. (2019). The Customers' Brand Identification with Luxury Hotels: A Social Identity Perspective. In Harrison, T. \& Brennan, M. (Eds.) 2019 AMS World Marketing Congress. University of Edinburgh, Scotland (July 2019). Academy of Marketing Science.

\begin{abstract}
This study explores the relationships between the consumer-brand identification (CBI) construct and the customers' satisfaction, commitment, trust and loyalty toward hospitality brands. The methodology included a confirmatory factor analysis (CFA) that assessed the reliability and validity of previous tried and tested measures in marketing sciences. This study has supported the scales' content validity. A two-step structural equation modelling approach was used to analyze the relationships among the latent and observed constructs. The findings have reported a satisfactory fit for this study's research model. The empirical results shed light on the direct and indirect effects on brand loyalty. This contribution implies that brand trust had the highest effect on brand loyalty, and this was followed my other determinants, including; consumer-brand identification, consumer satisfaction and commitment. In conclusion, this paper identifies its research limitations and puts forward possible research avenues.
\end{abstract}

Keywords: Social Identify Theory, Brand Loyalty, Customer-brand Identification, Satisfaction, Commitment, Trust, Hospitality.

\section{INTRODUCTION}

\footnotetext{
${ }^{1}$ The Business School, University of Jammu, Jammu and Kashmir, INDIA. Email: r.raouf18@gmail.com

${ }^{2}$ Department of Corporate Communication, Faculty of Media and Knowledge Sciences, University of Malta, Msida, MSD2080, MALTA. Email: mark.a.camilleri@um.edu.mt

The Business School, University of Edinburgh, Bucchleuch Place, Edinburgh, EH89JS, SCOTLAND.
} 
Relevant theoretical underpinnings on the social identity theory (SIT) suggests that the consumers' self-expressions are somewhat associated with their relationships with firms and brands (Rather \& Hollebeek, 2019; Fujita, Harrigan \& Soutar, 2018; Elbedweihy, Jayawardhena, Elsharnouby \& Elsharnouby, 2016; So, King \& Sparkes, 2014; So, King, Sparks \& Wang, 2013; Bhattacharya \& Sen, 2003). For this reason, this paper relied on the SIT perspective to explore the consumer-brand relationships (Elbedweihy et al., 2016; Lam, Ahearne, Mullins, Hayati, \& Schillewaert, 2013; Ahearne, Bhattacharya \& Gruen 2005).

The individual consumers form part of a social group who regularly experience the delivery of services (Fujita et al., 2018; Huang, Cheng, \& Chen, 2017; Elbedweihet al., 2016; So et al., 2013; Kuenzel \& Halliday, 2008; Bhattacharya \& Sen, 2003). Hence, the service brands can be considered as the facilitators of the consumers' social identity and expression as individuals can identify with brands if they perceive that they match their self-concept (Stokburger-Sauer, Ratneshwar, \& Sen, 2012; Homburg, Wieseke \& Hoyer, 2009). In a similar vein, the customerbrand identification (CBI) concept describes the relationships between the brands and their customers, as it explicates how the brands relate to the individuals' self-concept (Martinez \& Rodriguez del Bosque, 2013). Many brands are increasingly looking after their existing customers by satisfying their various needs, wants and desires (Chaudhuri \& Holbrook, 2001; Martinez \& Rodriguez del Bosque, 2014). They do so to retain their existing customers. The loyal customers are usually willing to pay more, spend more and recommend more than new prospects (Martinez \& Rodriguez del Bosque, 2014; Harris \& Goode, 2004).

The subject of brand loyalty has been explored extensively in the marketing literature. Past studies have often focused on the antecedents of loyalty, including; customer satisfaction (Popp \& Woratschek, 2017), trust (Martinez \& Rodriguez del Bosque, 2014; So et al., 2013), perceived service quality (So et al., 2013), commitment (Narteh, Agbemabiese, Kodua, \& 
Braimah, 2013; Su, Swanson, Chinchanachokchai, Hsu, \& Chen, 2016), customer engagement (Rather, Hollebeek \& Islam, 2019; So et al., 2014), as well as perceived value (So et al., 2013), among other constructs. Notwithstanding, CBI has been investigated in different research contexts, and has often yielded contradictory results. For instance, Su et al. (2016) indicated that brand identification was not significant in predicting customer loyalty. While other studies suggested that the relationship between customer retention, word-of-mouth and loyalty were positive and significant (Kuenzel \& Halliday, 2008); other research reported that there is a correlation between CBI and customer loyalty (Rather \& Hollebeek, 2019; Martinez \& Rodriguez del Bosque, 2013; 2014). However, the literature did not devote sufficient attention to discover the antecedents of CBI, albeit a few exceptions (Su et al., 2016; So et al., 2013; Keh \& Xie, 2009).

\section{Research Question}

Previous theoretical underpinnings and empirical studies have contributed to advancing our knowledge on brand loyalty and customer-brand relationships (Ahearne et al., 2005; Bhattacharya \& Sen, 2003; Fujita et al., 2018; He, Li, \& Harris, 2012; So et al., 2013). However, there is still a gap in the extent literature that explores CBI by using the social identity perspective (Ahearne, et al., 2005; Choo, Park, \& Petrick, 2011; Elbedweihy et al., 2016; He et al., 2012; Martinez and Rodriguez del Bosque, 2014; Popp \& Woratschek, 2017; So et al., 2013; Su et al., 2016). Hence, this paper addresses this lacuna in academic literature. The aim of this study is to provide further empirical evidence on the CBI construct (Keh \& Xie, 2009; Su et al., 2016). To the best of our knowledge, few studies have combined the social identity theory with social exchange factors to explain the determinants of hotel brand loyalty. Many researchers maintain that by incorporating the social identity (Rindfleisch, Burroughs, \& Wong, 2009; Homburg et al., 2009; Tajfel \& Turner, 1986) and the service dynamics (Harris \& Goode, 2004; Martinez \& Rodriguez del Bosque, 2014) they would better understand the 
psychological processes that are linked to brand loyalty. Prior empirical studies in the hospitality context did not incorporate certain aspects of brand loyalty, including the mediating effects of commitment, satisfaction and trust. Hence, this research differentiates itself from other contributions; by building on the foundations of previous research on the social identity perspective of customer-brand loyalty. However, it considers the direct and indirect effects of social exchange variables from the marketing science literature, to explore the causal path from CBI to brand loyalty. In sum, this study addresses the following research questions: (i) How is CBI related to customer satisfaction? (ii) How is CBI related to trust? (iii) Is CBI different from customer commitment? (iv) Are CBI, customer satisfaction and commitment influencing brand loyalty?

\section{LITERATURE REVIEW}

\section{Customer-brand Identification}

Hospitality and tourism researchers have described CBI as an important, yet under-utilized construct (Bhattacharya \& Sen, 2003; Martinez \& Rodriguez del Bosque, 2013). Identification takes place when individuals consider themselves as psychologically entangled with the characteristics of the group (So et al., 2013). Academic research has consensually defined CBI as a customer's psychological state of perceiving, valuing and feeling his or her belongingness with a brand (Lam et al., 2013). Customers do not only have a personal identity. They also possess a social identity (Choo et al., 2011). Therefore, persons could identify with firms even if they lack a formal membership with them. Since consumers have a need for building their sense of self (self-definition), they may usually express, identify and relate themselves with brands (Keh \& Xie, 2009; Choo et al., 2011). Bhattacharya and Sen (2003) have suggested that strong customer-company relationships are initially based on the customers' identification with the firms. The firms satisfy one or more of the individuals; self-definitional needs (e.g., selfcontinuity, self-enhancement and self-distinctiveness). This argumentation reflects the social 
identity theory as well as the organizational identification theory, as these theoretical underpinnings shed light on the customers' relationships with brands/companies. Thus, the higher the identification with a brand or organization, the more the customer is expected to be content with the firms' offerings/services. This will in turn lead to positive outcomes, including; positive word-of-mouth, willingness to try new products/services, and resilience to negative publicity, and the like (Bhattacharya \& Sen, 2003; Underwood, Bond \& Baer, 2001).

\section{Brand Loyalty}

Brand loyalty has also been recognized as a significant indicator of marketing success in various industries, including hospitality and tourism (Liat, Mansori, Chuan, \& Imrie, 2017; Martinez \& Rodriguez del Bosque, 2014; So et al., 2013). This construct has emerged as one of the most imperative goals of marketing and has proved to be one of the central drivers of profit (Camilleri, 2018; Narteh et al., 2013; Popp \& Woratschek, 2017). It combines both attitudes and behaviors (Martinez \& Rodriguez del Bosque, 2014). Loyalty incorporates the customers' revisit/repurchase intention (behavioral loyalty) as well as their willingness and positive tendencies to recommend the business to other prospects (Jani \& Han, 2011). These favorable behaviors and attitudes represent two essential aspects of customer loyalty (Martinez \& Rodriguez del Bosque, 2013). Thus, brand loyalty may often reflect the attitudinal as well as the behavioral aspects of repeat customers.

\section{Trust}

Both trust and commitment are considered by various researchers as the pillars of relationship marketing because these constructs can result in desirable outcomes for the business (Morgan \& Hunt, 1994). The relationship marketing theory suggests that; trust and commitment are central mediators between corporate activities and customer loyalty (Chaudhuri \& Holbrook, 2001; Martinez \& Rodriguez del Bosque, 2013). Trust has often been defined as the level of 
confidence among different parties. It involves relational qualities such as integrity, honesty, benevolence, consistency, and competency (Morgan \& Hunt, 1994). In this study, trust comprises two major components: (1) benevolence trust, as well as (2) performance or credibility trust.

\section{Commitment}

Commitment is often considered as one of the relationship marketing concepts (HennigThurau, Gwinner, \& Gremler, 2002; Morgan \& Hunt, 1994). This construct also has its roots in the social exchange theory. Moorman, Zaltman, and Deshpande (1992) defined commitment as "an enduring desire to maintain a valued relationship" (p. 316). In addition, several researchers have verified that both trust and commitment are vital factors that can make or break long-term relationships among business partners (Hennig-Thurau et al., 2002; Morgan \& Hunt, 1994). Therefore, this study builds on the extant literature as it defines customer commitment as the willingness of different parties to nurture genuine relationships (Morgan \& Hunt, 1994).

\section{Customer Satisfaction}

Customer satisfaction is yet another, indispensable relationship marketing concept. It has been related to the overall evaluation of performance of a company and is often perceived as a prime objective for managers (Anderson, Fornell \& Lehmann, 1994). Satisfaction is a strong predictor of intentions to revisit a service provider in the future. The level of customer satisfaction on products and services will have an effect on their behavioral intention to re-purchase them (Song, Van der Veen \& Chen. 2011; Bai, Law \& Wen, 2008). It can also lead individuals to make positive recommendations and referrals (Su et al., 2016; Liat et al., 2017).

\section{Customer-Brand Identification and Customer Commitment}


Martinez and Rodriguez del Bosque (2013) held that there was a research gap on CBI in the marketing literature. They also argued that this construct is closely related to other social exchange variables like customer commitment. Keh and Xie (2009) recommended that both identification and commitment portray the strong linkage between corporate reputation and the individuals' behavioral intention. Ashforth \& Mael (1989) suggested that identification reveals the individuals' self-definition, while commitment does not. As commitment is conceptualized as an attitude with the company, identification is a cognitive construct which reveals the extent to which the corporate features are entangled in the consumers' self-concept (Ashforth \& Mael, 1989). Previous research reported that consumers' identification with the brand is a crucial variable for the development of their commitment (Keh \&Xie, 2009; Tuskej, Golob \& Podnar, 2013). This argumentation leads to our first hypothesis:

Hypothesis One: Customer-brand identification is positively associated with commitment.

\section{Customer-Brand Identification and Customer Satisfaction}

To date, there were limited empirical studies that have incorporate customer satisfaction and CBI (Rather \& Hollebeek, 2019; Rather et al., 2019; Popp \& Woratschek, 2017). However, CBI has recently been identified as a critical variable that predicts customer-brand relationships. The customers may identify themselves with the brands that satisfy their needs and wants (Camilleri, 2017; Bhattacharya \& Sen, 2003; He \& Li, 2011). On the other hand, if the customers' expectations are not satisfied, they will not engage with the brand (Chaudhuri \& Holbrook, 2001). Thus, this argumentation suggests that those customers who exhibit stronger levels of identification with the firm will probably experience increased satisfaction levels. Hence, we hypothesize:

Hypothesis Two: Customer-brand identification has a positive relationship with satisfaction 


\section{Customer-Brand Identification and Brand Trust}

Previous tourism and hospitality research did not focus enough on the direct influence of customer-brand identification or brand congruence on trust, or on consumers' attachment with the brands and their trust towards the brand (So et al., 2013). For instance, the affluent customers would probably trust prestige brands, as they may be congruent with their self-image (Han \& Hyun, 2013). Similarly, this argumentation can be extended to the CBI concept. Thus, we maintain that:

Hypothesis Three: Customer-brand identification is positively associated with brand trust

\section{Customer-Brand Identification and Brand Loyalty}

There have been few theoretical underpinnings that have linked the customer-brand identification with the consumers' loyalty towards brands (Martinez \& Rodriguez del Bosque, 2013, 2014; So et al., 2013). Previous literature suggested that the social identity can influence the individuals' cognitions, perceptions and evaluation of products and services (Fujita et al., 2018; Tajfel \& Turner, 1986). Therefore, the customers' identification with a service offering or a brand can trigger positive outcomes, like increased brand loyalty (Kuenzel \& Halliday, 2008; Underwood et al., 2001). The customers who identify themselves with the firms would not only acquire products from them, but may also develop a closer relationship with them (Camilleri, 2018; Bhattacharya \& Sen, 2003). Hence, we put forward the following hypothesis:

Hypothesis Four: Customer-brand identification positively impacts brand loyalty.

\section{Customer Satisfaction and Customer Commitment}


When customers are satisfied with their brand experience, they may usually feel a positive attitude toward the brand. As a result, they may be intrigued to engage in a relationship with the brand (Martinez \& Rodriguez del Bosque, 2013. Liat et al., 2017). Prior research found that the customers continuously evaluate their experiences with brands (Bowden, 2009). Hence, the satisfied customers will feel committed toward the brand (Sung \& Campbell, 2009; Morgan \& Hunt, 1994). This leads to our fifth hypothesis.

Hypothesis Five: Customer satisfaction has a positive association with customer commitment.

\section{Brand Trust and Customer Commitment}

The consumer trust is an antecedent of brand commitment as it is prerequisite for customerbrand relationships with customers (Camilleri, 2018; Morgan \& Hunt, S.1994; Moorman et al., 1992). Several studies consistently reiterate that trust leads to commitment (Keh \& Xie, 2009). Martinez \& Rodriguez del Bosque (2014) also maintained that trust is one of the most important antecedents of customer-brand relationships, in the context of upscale hotels. Hence, this study proposes that trust would have a positive influence on customer commitment.

Hypothesis Six: Brand trust will positively impact hotel customer commitment.

\section{Customer Satisfaction and Brand Trust}

There is a close relationship between satisfaction and trust (Martinez \& Rodriguez del Bosque, 2013). The customers' satisfaction is an essential driver of brand trust (Bowden, Dagger, \& Elliott, 2013). Brand trust is evidenced when the customers engage in a relationship with businesses as they regularly use the firms' products or services (Bowden et al., 2013). The consumers' relationships with the businesses, as well as their ongoing satisfactory experiences 
with their products or services will inevitably have an effect on their brand trust (Martinez \& Rodriguez del Bosque, 2013). Hence, we argue that customer satisfaction leads to brand trust.

Hypothesis Seven: Customer satisfaction has been positively associated with brand trust.

\section{Customer Commitment and Brand Loyalty}

The consumers' commitment toward the brand positively influence their behaviours. Moreover, the loyal consumers will usually demonstrate greater levels of brand commitment (Su et al., 2016; Narteh et al., 2013). Similarly, the customer commitment has been identified to be one of the antecedents of hotel brand loyalty (Narteh et al., 2013). Hence, we hypothesise that the customers' commitment towards the hospitality brand is an important driver for their brand loyalty.

Hypothesis Eight: Customer commitment has been positively related to brand loyalty.

\section{Customer Satisfaction and Brand Loyalty}

Several academic studies have examined the relationship between consumer satisfaction on the products or services they acquired with their loyalty towards the brand (Song et al., 2011; Caruana, 2002). There were also a number of empirical studies in the tourism and hospitality context; that have proved that there was a positive relationship between customer satisfaction and loyalty (Liat et al., 2017; Nam, Ekinci \& Whyatt, 2011). Other findings did not establish a significant relationship between satisfaction and loyalty (Al-Wugayan, Pleshko \& Baqer, 2008). Therefore, this study investigates this relationship, as we hypothesise the following:

Hypothesis Nine: Customer satisfaction has been positively related to hotel brand loyalty. 


\section{Brand Trust and Brand Loyalty}

Previous literature suggested that the consumers' loyalty towards brands is related to their trust in those brands (Martinez \& Rodriguez del Bosque, 2014; Narteh et al., 2013). Trust is also considered an important determinant for building relationships in the hospitality context (Martinez \& Rodriguez del Bosque, 2013). The positive relationships among relational constructs, including; trust and commitment with brand loyalty has often been proved in the marketing literature (Huang, 2017; Hennig-Thurau et al., 2002; Chaudhuri \& Holbrook, 2001). The consumers' trust leads to improved relationships with businesses, that may accentuate brand loyalty (He et al., 2012; Morgan \& Hunt, 1994). Recently, Su et al. (2016) have also examined the influence of CBI on the consumers' repurchase intensions as they explored the effects of the consumers' satisfaction and commitment as mediating variables. In a similar vein, we posit that customer commitment, customer satisfaction and brand trust could mediate the effects of CBI on hotel brand loyalty. This, leads to the following hypotheses:

Hypothesis Ten: Brand trust has a positive relationship with brand loyalty.

Hypothesis Eleven: Customer commitment, trust and satisfaction mediate the relationship between CBI and hotel brand loyalty.

\section{The Research Model}

This study is based on the conceptual developments appertaining to: (i) the social identity theory, (ii) customer relationship marketing theory, as well as (iii) the customer satisfaction model of expectation disconfirmation theory. Firstly, CBI explains the motivations why individuals relate to firms. This is consistent with reasoning behind the social identity theory (SIT) (Tajfel \& Turner, 1986). SIT suggests that people are inclined to associate themselves with successful groups, particularly when such affiliation offers them higher status or a better identity (Bhattacharya \& Sen, 2003). Social identity has cognitive, affective, and evaluative 
elements that are activated in different social realities (Fujita et al., 2018). Secondly, the customer relationship marketing theory explains how the customer-brand relationships may or may not improve the brand equity and could therefore contribute to an increase or a decrease in the firm's profitability (Camilleri, 2018). In the hospitality context, upscale hotel brands are increasingly nurturing relationships with profitable customers as they help them to improve their bottom line (Camilleri, 2017; So et al., 2013; Su et al., 2016). Thirdly, the customer satisfaction model of expectation disconfirmation theory suggests that the consumers are more satisfied and content, when the businesses or brands would exceed their expectations (Camilleri, 2017; Oliver, 1997). In this light, this study, explores the relationships between five constructs, including; customer-brand identification, customer satisfaction, customer commitment, customer trust and brand loyalty, as shown in Figure 1.

\section{Figure 1 The Research Model}

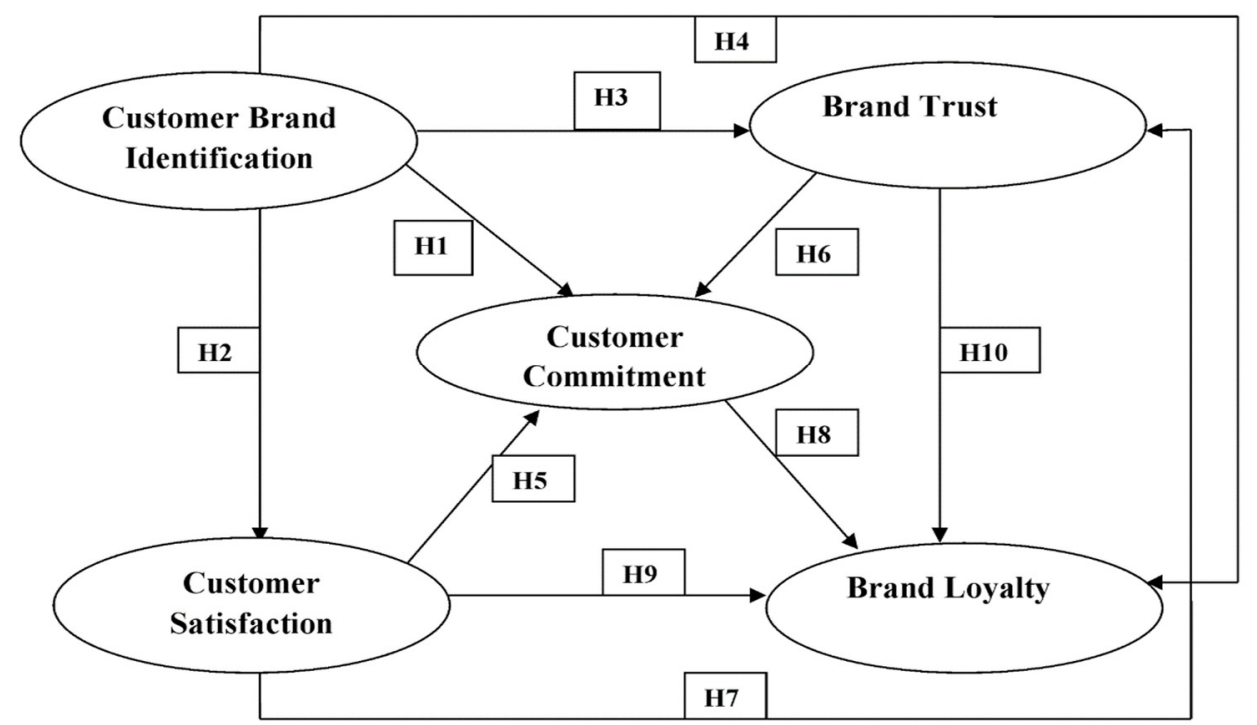

\section{RESEARCH METHODOLOGY}

\section{The Measures}

The research participants were expected to indicate the extent of their agreement with the survey items, in a seven-point Likert scale. The responses ranged from 1= "strongly disagree" 
to $7=$ "strongly agree", where 4 signaled an indecision. This study adapted valid and reliable measures that were tried and tested in academia. There were four items appertaining to Customer-brand Identification (So et al., 2013), Customer Satisfaction (Martinez \& Rodriguez del Bosque, 2013), Customer Commitment (Su et al., 2016), Brand Trust (So et al., 2013). Moreover, it relied on six items to measure Brand Loyalty (Martinez \& Rodriguez del Bosque, 2014).

At the preliminary stage, the questionnaire was pre-tested by four hospitality managers and by three marketing academics to confirm that the survey items were clear and comprehensible for the respondents (Hair, Black, Babin, \& Anderson, 2010). Their responses suggested that the measuring items were understandable. The respondents were given the opportunity to seek further explanations regarding the questionnaires' content to further reduce the errors related to the measurement. This has helped the researchers to improve the validity of this study.

\section{Data Collection}

Data was collected from hotel guests who stayed in four or five-star accommodation establishments that belonged to one of the hotel chains, including; Vivanta by Taj, Grand Lalith, Khyber Resorts, Radisson Blu, Best Western, Holiday Inn and Hyatt. The study was carried out in six Indian cities, namely; Srinagar, Gulmarg, Phalgam, Jammu, Katra and Amritsar. The questionnaires were distributed to customers at different times of the day, over a five-week period. There were 345 respondents out of one thousand and sixty who have voluntarily decided to take part in this study. 


\section{ANALYSIS AND RESULTS}

\section{The Socio-Demographic Profile of the Respondents}

A descriptive analysis of the respondents indicates that $54 \%$ were male while $46 \%$ were female.

The majority of the respondents were between 31 and 50 years of age $(n=221)$. Most of them decided to stay in a four-star accommodation establishment $(n=231)$, as illustrated in Table 1. Interestingly, one third of the respondents were repeat (loyal) customers.

Table 1 Demographic Profile and Travel Behaviour of the Respondents

\begin{tabular}{|l|l|l|l|l|l|}
\hline \multicolumn{1}{|c|}{ Gender } & N & $\%$ & Hotel Brand & N & $\%$ \\
\hline Female & 160 & 46 & Four Star & 231 & 67 \\
\hline Male & 185 & 54 & Five Star & 114 & 33 \\
\hline Total & $\mathbf{3 4 5}$ & $\mathbf{1 0 0}$ & Total & $\mathbf{3 4 5}$ & $\mathbf{1 0 0}$ \\
\hline & & & & & \\
\hline Age & $\mathbf{N}$ & $\mathbf{\%}$ & Customer Status & N & $\%$ \\
\hline $21-30$ & 74 & 21 & First Time Customer & 235 & 68 \\
\hline $31-40$ & 130 & 37 & Repeat Customer & 111 & 32 \\
\hline $41-50$ & 91 & 27 & Total & $\mathbf{3 4 6}$ & $\mathbf{1 0 0}$ \\
\hline $51-60$ & 45 & 13 & & & \\
\hline $61-70$ & 5 & 1 & & & \\
\hline Over 71 & 0 & 0 & & & \\
\hline Total & $\mathbf{3 4 5}$ & $\mathbf{1 0 0}$ & & & \\
\hline & & & & & \\
\hline
\end{tabular}

\section{Descriptive Analysis}

Generally, the respondents indicated that they agreed with the survey items, except for the CBI construct, as reported in Table 2. Moreover, the standard deviations indicated that there was a narrow spread of participants' responses, ranging from 0.4 to 1.47 , indicating a narrow spread around the mean. 
Table 2 Measurement items, mean, standard deviation and squared multiple correlation

\begin{tabular}{|l|l|l|l|l|}
\hline Construct & SL & M & SD & SMC \\
\hline Customer-brand Identification (CBI) & & & & \\
\hline $\begin{array}{l}\text { It feels like a personal insult when someone criticizes this } \\
\text { brand }\end{array}$ & 0.81 & 3.06 & 1.47 & 0.65 \\
\hline $\begin{array}{l}\text { When I refer to this brand, I usually say "my" rather than } \\
\text { "they" }\end{array}$ & 0.86 & 3.95 & 1.43 & 0.74 \\
\hline This brand's successes are my successes & 0.90 & 4.16 & 1.32 & 0.81 \\
\hline $\begin{array}{l}\text { When someone praises this brand, it feels like a personal } \\
\text { compliment }\end{array}$ & 0.85 & 4.79 & 1.12 & 0.72 \\
\hline Brand Trust (BT) & & & & \\
\hline I trust this brand & 0.98 & 5.42 & 1.04 & 0.96 \\
\hline This is an honest brand & 0.97 & 5.46 & 1.00 & 0.93 \\
\hline This brand is safe & 0.73 & 5.87 & 0.40 & 0.53 \\
\hline I rely on this brand & 0.90 & 5.47 & 0.93 & 0.80 \\
\hline Customer Satisfaction (CS) & & & & \\
\hline I am satisfied with my decision to visit this brand & 0.92 & 5.09 & 1.18 & 0.84 \\
\hline My choice to choose this brand was a wise one & 0.94 & 4.95 & 1.21 & 0.88 \\
\hline I feel that my experience with this brand has been enjoyable & 0.82 & 4.89 & 1.19 & 0.67 \\
\hline I think I did the right thing to visit this brand & 0.95 & 4.99 & 1.12 & 0.89 \\
\hline Customer Commitment (CC) & & & & \\
\hline I feel committed to this brand & 0.92 & 4.63 & 1.26 & 0.84 \\
\hline I am proud to belong to this brand & 0.68 & 4.72 & 1.09 & 0.45 \\
\hline I am a loyal customer of this brand & 0.91 & 4.54 & 1.24 & 0.83 \\
\hline I hope for the long-term success of this brand & 0.95 & 4.54 & 1.24 & 0.90 \\
\hline Brand Loyalty (BL) & & & & \\
\hline $\begin{array}{l}\text { I would recommend this brand to someone who seeks my } \\
\text { advice }\end{array}$ & 0.89 & 5.32 & 1.04 & 0.78 \\
\hline $\begin{array}{l}\text { I would encourage friends and relatives to do business with } \\
\text { this brand }\end{array}$ & 0.83 & 5.21 & 1.12 & 0.85 \\
\hline I would say positive things about this brand to other people & 0.94 & 5.12 & 1.16 & 0.88 \\
\hline $\begin{array}{l}\text { I would do more business with this brand in the next few } \\
\text { years }\end{array}$ & 0.80 & 4.57 & 1.25 & 0.63 \\
\hline I am a loyal customer of this brand & 0.86 & 4.51 & 1.32 & 0.73 \\
\hline I am willing to maintain my relationship with this brand & 0.88 & 4.60 & 1.36 & 0.77 \\
\hline
\end{tabular}

Note: $\mathrm{SL}=$ standard loadings, $\mathrm{M}=$ mean, $\mathrm{SD}=$ standard deviation, $\mathrm{SMC}=$ squared multiple correlation

\section{Measurement Model}

The measurement model involved a confirmatory factor analysis (CFA). This was conducted through Structural Equation Modelling using Amos in order to assess the uni-dimensionality, validity and reliability of the constructs. CFA removed the items that did not fit the measurement model due to low factor loading. The researcher conducted a pooled CFA to 
assess the measures of the latent constructs. The overall goodness-of-fit indices of CFA indicated that all the fits of the measurement model are satisfactory (CFI, TLI, GFI, and NFI $>0.90$; RMSEA $<0.08$ (Bentler \& Bonett, 1980). The overall the measurement model of the CFA is achieved excellent fit $\chi 2=572.540, \mathrm{df}=197, \chi 2 / \mathrm{df}=2.906, \mathrm{p}<.000, \mathrm{CFI}=0.96$; TLI $=0.95, \mathrm{NFI}=0.94, \mathrm{GFI}=0.88, \mathrm{RMSEA}=0.074, \mathrm{SRMR}=0.47)$.

\section{Reliability and Validity of Scales}

In addition, CFA assessed the reliability as well as validity of all scales. Convergent validity was confirmed by analysing the conditions suggested by (Fornell \& Larcker, 1981). At first, all CFA factor loadings were statistically significant at $p<0.001$. Furthermore, all the indicators for all the measurement constructs were significant (critical values were higher than 1.96) and the AVE were higher than 0.5, suggesting convergent validity of the scale or unidimensionality of the constructs (Fornell \& Larcker, 1981). Finally, the reliabilities for each construct were above the value of 0.70 , fulfilling the general condition of reliability for the research instruments, as shown in Table 3.

Table 3 Discriminant validity, reliability and correlation values

\begin{tabular}{|l|c|c|c|c|c|c|c|c|}
\hline Construct & $\boldsymbol{\alpha}$ & $\mathbf{C R}$ & AVE & BL & CBI & CS & CC & BT \\
\hline BL & 0.955 & 0.954 & 0.777 & $\mathbf{0 . 8 8 2}$ & & & & \\
\hline CBI & 0.91 & 0.917 & 0.733 & 0.803 & $\mathbf{0 . 8 5 6}$ & & & \\
\hline CS & 0.948 & 0.95 & 0.826 & 0.816 & 0.786 & $\mathbf{0 . 9 0 9}$ & & \\
\hline CC & 0.921 & 0.925 & 0.757 & 0.82 & 0.833 & 0.853 & $\mathbf{0 . 8 7}$ & \\
\hline BT & 0.922 & 0.944 & 0.809 & 0.791 & 0.641 & 0.718 & 0.713 & $\mathbf{0 . 8 8 9}$ \\
\hline
\end{tabular}

Note: $\alpha=$ Cronbach's alpha, AVE = average variance extracted, $\mathrm{CR}=$ construct reliability, $\mathrm{BL}=$ brand loyalty, $\mathrm{CBI}=$ customer-brand identification, $\mathrm{BT}=$ brand trust, $\mathrm{CS}=$ customer satisfaction, $\mathrm{CM}=$ customer commitment. Off diagonal factors are the correlations among the study constructs. 
To confirm the discriminant validity the researchers evaluated the correlations of the constructs with the square root of the average variance extracted for each of the constructs (Fornell \& Larcker, 1981). Table 3 indicates that the AVE is higher than its squared correlations of any pair of two constructs. This finding supports the discriminant validity of the constructs. Moreover, the results of the specific chi-square difference test for CBI and commitment $\chi^{2}=$ $102.347, \mathrm{df}=19, \chi 2 / \mathrm{df}=5.387, \mathrm{p}<.000$ or $(\Delta \chi 2=5.387, \mathrm{p}=.000)$ showed that these two closely related constructs differed significantly. Hence there was discriminant validity between identification and commitment as the two redundancy constructs were different.

\section{The Structural Equation Modelling (SEM)}

The overall structural model was tested by means of AMOS 20.0 with maximum likelihood estimation. The overall model fitness indices $\chi^{2}=572.540, d f=197, \chi 2 / d f=2.906, \mathrm{CFI}=.96$, $\mathrm{TLI}=.95, \mathrm{NFI}=.94, \mathrm{GFI}=0.88, \mathrm{RMSEA}=.074$, and $\mathrm{SRMR}=0.48$ reported an optimal model fit.

All the structural path coefficients were found to be positive and significant. The current study reported significant influences particularly in $\mathrm{H} 2$, between $\mathrm{CBI}$ and satisfaction, where $\beta=$ $0.79, \mathrm{R}^{2}=0.62, \mathrm{p}<0.05$. There were also significant relationships between $\mathrm{CBI}$ and customer commitment (H1) where $\beta=0.40, \mathrm{R}^{2}=0.81, \mathrm{p}<0.05$; between $\mathrm{CBI}$ and brand loyalty $(\mathrm{H} 4)$, where $\beta=0.29, R^{2}=0.80, p<0.05$; and between $C B I$ and brand trust $(H 3)$, where $\beta=0.20, R^{2}$ $=0.53, \mathrm{p}<0.05$.

Satisfaction had a significant positive influence on commitment (H5), where $\beta=0.44, R^{2}=$ $0.81, \mathrm{p}<0.05$, whilst brand trust had a very significant effect on customer commitment (H6), where $\left.\beta=0.14, R^{2}=0.81, p<0.01\right)$. Satisfaction also had a significant and an effect on brand trust $(\mathrm{H} 7)$, where $\left.\beta=0.29, \mathrm{R}^{2}=0.53, \mathrm{p}<0.05\right)$. Moreover, the findings suggest that 
commitment was an antecedent of brand loyalty (H8), where $\beta=0.16, \mathrm{R}^{2}=0.80, \mathrm{p}<0.05$ ); and satisfaction had a small, significant effect on brand loyalty (H9), where $\beta=0.21, R^{2}=0.80, p$ $<.05$. Notwithstanding, this study has shown that brand trust is also a highly significant driver of brand loyalty $(\mathrm{H} 10)$, where $\beta=0.35, \mathrm{R}^{2}=0.80, \mathrm{p}<0.005$. The brand trust $(\beta=0.35)$ had a higher effect on brand loyalty than CBI $(\beta=0.29)$, satisfaction $(\beta=0.21)$ and commitment $(\beta$ $=0.16$ ). Therefore, the consumers' trust in the brand determined their loyalty. The results from the structural equation modelling are reported in Table 4.

Table 4 Structural equation model results

\begin{tabular}{|c|l|c|c|c|c|}
\hline $\mathbf{H}$ & Structural Relationships & $\mathbf{R}^{\mathbf{2}}$ & $\boldsymbol{\beta}$ & $\mathbf{T}$ & \\
\hline H1 & customer-brand identification $\rightarrow$ customer commitment & 0.81 & 0.4 & 7.38 & Sig \\
\hline H2 & customer-brand identification $\rightarrow$ customer satisfaction & 0.62 & 0.79 & 16.53 & Sig \\
\hline H3 & customer-brand identification $\rightarrow$ brand trust & 0.5 & 0.2 & 2.83 & Sig \\
\hline H4 & customer-brand identification $\rightarrow$ brand loyalty & 0.8 & 0.29 & 4.64 & Sig \\
\hline H5 & customer satisfaction $\rightarrow$ customer commitment & 0.81 & 0.44 & 7.71 & Sig \\
\hline H6 & brand trust $\rightarrow$ customer commitment & 0.84 & 0.14 & 3.43 & Sig \\
\hline H7 & customer satisfaction $\rightarrow$ brand trust & 0.53 & 0.29 & 8.03 & Sig \\
\hline H8 & customer commitment $\rightarrow$ brand loyalty & 0.81 & 0.16 & 2.75 & Sig \\
\hline H9 & customer satisfaction $\rightarrow$ brand loyalty & 0.8 & 0.21 & 3.21 & Sig \\
\hline H10 & brand trust $\rightarrow$ brand loyalty & 0.83 & 0.35 & 7.88 & Sig \\
\hline
\end{tabular}

The overall model fitness indices: $\chi 2=572.540$

$d f=197, \chi 2 / d f=2.906, \mathrm{CFI}=.96, \mathrm{TLI}=.95, \mathrm{NFI}=.94, \mathrm{GFI}=0.88, \mathrm{RMSEA}=.074, \mathrm{SRMR}=0.48$

Taking into reflection the indirect effects in the model, CBI had the strongest indirect effect on hotel brand loyalty $(\beta=0.51)$ followed by the customer satisfaction $(\beta=0.27)$. Brand trust had a minimal indirect effect on brand loyalty $(\beta=0.023)$. Furthermore, commitment, brand trust and satisfaction significantly mediated the relationship between CBI and hotel brand loyalty. The indirect, direct, and total effects are reported in Table 5. 
Direct and

Indirect Effects

CBI CS BT CM BL

\section{CS}
1. Direct path effect
$\begin{array}{lllll}0.786 & 0.000 & 0.000 & 0.000 & 0.000\end{array}$
2. Indirect path effect
$\begin{array}{lllll}0.000 & 0.000 & 0.000 & 0.000 & 0.000\end{array}$
3. Total effect
$\begin{array}{lllll}0.786 & 0.000 & 0.000 & 0.000 & 0.000\end{array}$

BT
1. Direct path effect
$\begin{array}{lllll}0.200 & 0.561 & 0.000 & 0.000 & 0.000\end{array}$
2. Indirect path effect
$\begin{array}{lllll}0.441 & 0.000 & 0.000 & 0.000 & 0.000\end{array}$
3. Total effect
$\begin{array}{lllll}0.641 & 0.561 & 0.000 & 0.000 & 0.000\end{array}$

\section{$\mathrm{CM}$}
1. Direct path effect
$\begin{array}{lllll}0.396 & 0.437 & 0.145 & 0.000 & 0.000\end{array}$
2. Indirect path effect

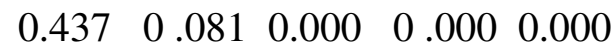
3. Total effect
$\begin{array}{llllll}0.833 & 0.519 & 0.145 & 0.000 & 0.000\end{array}$

BL
1. Direct path effect
$\begin{array}{lllll}0.287 & 0.207 & 0.346 & 0.159 & 0.000\end{array}$
2. Indirect path effect

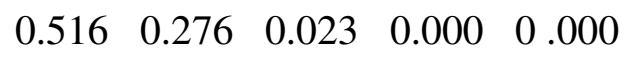
3. Total effect
$\begin{array}{lllll}0.803 & 0.483 & 0.369 & 0.159 & 0.000\end{array}$

\section{CONCLUSIONS AND IMPLICATIONS}

A social identity lens was used to advance our understanding of consumer-brand identity in the hospitality context. This study has built on the extant knowledge relating to the social identity theory as well as on relationship marketing literature (Ahearne et al., 2005; Fujita et al., 2018; Lam et al., 2013; Martinez \& Rodriguez del Bosque, 2014; So et al., 2013), and empirically tested the relationships between consumer-brand identity and consumer commitment, trust and 
satisfaction. At the same time, it explained these constructs' direct and its indirect influences on hotel brand loyalty. In a nutshell, the results indicated that satisfaction, commitment and trust are antecedents of CBI, that would in turn lead to brand loyalty. This paper puts forward important implications to academia and practitioners on brand identification and brand loyalty literature. To the best of our knowledge, there were no other studies that have empirically investigated this integrated research model within the hospitality context. Moreover, this contribution identified the key antecedents or drivers of the consumers' loyalty towards hotels.

We recognize that all studies may have their inherent limitations. Firstly, we are aware that this empirical research has relied on cross-sectional data. Therefore, in future, a longitudinal study could possibly be used to examine the relationship of these constructs over a longer time span. Secondly, the data for this research was gathered from the hospitality industry context. Future research could replicate the findings from this study across different sectors, or in other countries. Further research could employ different constructs from the marketing sciences. In conclusion, we believe that there is scope for future research to identify other drivers and consequences of hospitality brand identification and brand loyalty. Other research can explore the emerging themes of customer-brand engagement, including; co-creation and service innovation, among other topics.

\section{Acknowledgements}

The authors thank the hotel managers who have allowed us to use their premises to gather the data among their guests. We are also grateful to the reviewers of the AMS World Marketing Congress 2019, who have provided us with insightful remarks and suggestions.

\section{REFERENCES}

Ahearne, M., Bhattacharya, C. B., \& Gruen, T. (2005). Antecedents and consequences of customer-company identification: expanding the role of relationship marketing. Journal of Applied Psychology, 90(3), 574-585. 
Al-Wugayan, A., Pleshko, L., \& Baqer, S. (2008). An investigation of the relationships among consumer satisfaction, loyalty, and market share in Kuwaiti loan services. Journal of Financial Services Marketing, 13(2), 95-106.

Anderson, E. W., Fornell, C., \& Lehmann, D. R. (1994). Customer satisfaction, market share, and profitability: findings from Sweden. Journal of Marketing, 5(8), 53-66.

Ashforth, B. E., \& Mael, F. (1989). Social identity theory and the organization. Academy of Management Review, 14, 20-39.

Bai, B., Law, R., \& Wen, I. (2008). The impact of website quality on customer satisfaction and purchase intentions: Evidence from Chinese online visitors. International journal of hospitality management, 27(3), 391-402.

Bentler, P. M., \& Bonnett, D. G. (1980). Significance tests and goodness of fit in the analysis of covariance structures. Psychological Bulletin, 88(3), 588-606.

Bhattacharya, C. B., \& Sen, S. (2003). Consumer company identification: a framework for understanding consumers' relationships with companies. Journal of Marketing, 67(2), 76-88.

Bowden, J. L. H. (2009). The process of customer engagement: A conceptual framework. Journal of marketing theory and practice, 17(1), 63-74.

Bowden, J. L., Dagger, T, S., \& Elliott, G. (2013). Engaging customers for loyalty in the restaurant industry: the role of satisfaction, trust, and delight. Journal of Foodservice Business Research, 16(1), 52-75.

Camilleri, M. A. (2017). Understanding customer needs and wants. In Camilleri, M.A. (Ed.) Travel marketing, tourism economics and the airline product (pp. 29-50). Cham, Switzerland: Springer Nature.

Camilleri, M.A. (2018). The Marketing Environment of Tourist Destinations. In Camilleri, M.A. (Ed.) The Branding of Tourist Destinations: Theoretical and Empirical Insights. Bingley, UK: Emerald Publishing Limited.

Caruana, A. (2002). Service loyalty: The effects of service quality and the mediating role of customer satisfaction. European journal of marketing, 36(7/8), 811-828.

Chaudhuri, A., \& Holbrook, M. (2001). The chain of effects from brand trust and brand affect to brand performance: The role of brand loyalty. Journal of Marketing, 65(2), 81-93.

Choo, H., Park, S.Y., \& Petrick, J. F. (2011). The influence of the resident's identification with a tourism destination brand on their behavior. Journal of Hospitality Marketing \& Management, 20(2), 198-216.

Elbedweihy, A., Jayawardhena, C., Elsharnouby, M. H., \& Elsharnouby, T. H. (2016). Customer relationship building: The role of brand attractiveness and consumer-brand identification. Journal of Business Research, 69, 2901-2910

Fornell, C., \& Larcker, D. F. (1981). Evaluating structural equation models with unobservable variables and measurement error. Journal of Marketing Research, 18(1), 39-50. 
Fujita, M., Harrigan, P., \& Soutar, G. N. (2018). Capturing and co-creating student experiences in social media: a social identity theory perspective. Journal of Marketing Theory and Practice, 26(1-2), 55-71.

Hair, J. F., Anderson, R. E., Babin, B. J., \& Black, W. C. (2010). Multivariate data analysis: A global perspective (Vol. 7). Upper Saddle River, NJ: Pearson.

Han, H., \& Hyun, S. S. (2013). Image congruence and relationship quality in predicting switching intention conspicuousness of product use as a moderator variable. Journal of Hospitality \& Tourism Research, 37(3), 303-329.

Harris, L. C., \& Goode, M. M. H. (2004). The four levels of loyalty and the pivotal role of trust: a study of online service dynamics. Journal of Retailing, 80(2), 139-158.

He, H., \& Li, Y. (2011). CSR and service brand: the mediating effect of brand identification and moderating effect of service quality. Journal of Business Ethics, 100, 673-688.

He, H., Li, Y., \& Harris, L. (2012). Social identity perspective on brand loyalty. Journal of Business Research, 65, 648-657.

Hennig-Thurau, T., Gwinner, K. P., \& Gremler, D. D. (2002). Understanding relationship mmarketing outcomes: an integration of relational benefits and relationship quality. Journal of Service Research, 4(3), 230-247.

Homburg, C., Wieseke, J., \& Hoyer, W. D. (2009). Social identity and the service-profit chain. Journal of Marketing, 73(2) 38-54.

Huang, C. C. (2017). The impacts of brand experiences on brand loyalty: mediators of brand love and trust. Management Decision, 55(5), 915-934.

Huang, M. H., Cheng, Z. H., \& Chen, I. C. (2017). The importance of CSR in forming customer-company identification and long-term loyalty. Journal of Services Marketing, 31(1), 63-72.

Jani, D., \& Han, H. (2011). Investigating the key factors affecting behavioral intentions: Evidence from a full-service restaurant setting. International Journal of Contemporary Hospitality Management, 23(7), 1000-1018.

Keh, H. T., \& Xie, Y. (2009). Corporate reputation and customer behavioral intentions: The role of trust, identification and commitment. Industrial Marketing Management, 38, 732-742.

Kuenzel, S., \& Halliday, S.V. (2008). Investigating antecedents and consequences of brand identification. Journal of Product and Brand Management, 17, 293-304.

Lam, S. K., Ahearne, M., Mullins, R., Hayati, B., \& Schillewaert, N. (2013). Exploring the dynamics of antecedents to consumer-brand identification with a new brand. Journal of the Academy of Marketing Science, 41(2) 234-252.

Liat, C. B., Mansori, S., Chuan, G. C., \& Imrie, B. C. (2017). Hotel service recovery and service quality: influences of corporate image and generational differences in the relationship between customer satisfaction and loyalty. Journal of Global Marketing, 30(1), 42-51. 
Martinez, P., \& Rodriguez Del Bosque Rodriguez, I. (2013). CSR and customer loyalty: The roles of trust, customer identification with the company and satisfaction. International Journal of Hospitality Management, 35, 89-99.

Martinez, P., \& Rodriguez Del Bosque Rodriguez, I. (2014). Exploring the antecedents of hotel customer loyalty: A social identity perspective. Journal of Hospitality Marketing \& Management, 24(1), 1-23.

Moorman, C., Zaltman, G., \& Deshpande, R. (1992). Relationships between providers and users of marketing research: The dynamics of trust within and between organizations. Journal of Marketing Research, 29, 314-328.

Morgan, R., \& Hunt, S. (1994). The commitment-trust theory of relationship marketing. Journal of Marketing, 58, 20-38.

Narteh, B., Agbemabiese, G. C., Kodua, P., \& Braimah, M. (2013). Relationship marketing and customer loyalty: Evidence from the Ghanaian luxury hotel industry. Journal of Hospitality Marketing \& Management, 22(4), 407-436.

Nam, J., Ekinci, Y., \& Whyatt, G. (2011). Brand equity, brand loyalty and consumer satisfaction. Annals of tourism Research, 38(3), 1009-1030.

Oliver, R.L., (1997). Satisfaction: A Behavioral Perspective on the Consumer. McGraw- Hill, New York.

Popp, B., \& Woratschek, H. (2017). Consumer-brand identification revisited: an integrative framework of brand identification, customer satisfaction, and price image and their role for brand loyalty and word of mouth. Journal of Brand Management, 1-21.

Rather, R. A., \& Hollebeek, L. D. (2019). Exploring and validating social identification and social exchange-based drivers of hospitality customer loyalty.

International Journal of Contemporary Hospitality Management. https://www.emeraldinsight.com/doi/abs/10.1108/IJCHM-10-2017-0627

Rather, R. A., Hollebeek, L. D., \& Islam, J. U. (2019). Tourism-based customer engagement: the construct, antecedents, and consequences. The Service Industries Journal. https://www.tandfonline.com/doi/abs/10.1080/02642069.2019.1570154?journalCode=fsij20

Rindfleisch, A., Burroughs, J., \&Wong, N. (2009). The safety of objects: materialism, existential insecurity, and brand connection. Journal of Consumer Research, 36(1), 1-16.

So, K. K. F., King, C., Sparks, B., \& Wang, Y. (2013). The influence of customer-brand identification on hotel brand evaluation and loyalty development. International Journal of Hospitality Management, 34, 31-41.

So, K. K. F., King, C., \& Sparks, B. (2014). Customer engagement with tourism brands: Scale development and validation. Journal of Hospitality \& Tourism Research, 38(3), 304-329.

Song, H., Li, G., van der Veen, R., \& Chen, J. L. (2011). Assessing mainland Chinese tourists satisfaction with Hong Kong using tourist satisfaction index. International Journal of Tourism Research, 13, 82-96. 
Stokburger-Sauer, N., Ratneshwar, S, \& Sen, S. (2012) Drivers of consumer-brand identification. International Journal of Research in Marketing, 29(4), 406-418.

Su, L., Swanson, S. R., Chinchanachokchai, S., Hsu, M. K., \& Chen, X. (2016). Reputation and intentions: the role of satisfaction, identification, and commitment. Journal of Business Research, 69(9), 3261-3269.

Sung, Y., \& Campbell, W. K. (2009). Brand commitment in consumer-brand relationships: An investment model approach. Journal of Brand Management, 17(2), 97-113.

Tajfel, H., \& Turner, J. C. (1986). The social identity theory of inter-group behavior. In S. Worchel \& L. W. Austin (Eds.), Psychology of intergroup relations (pp. 7-24). Chicago, IL: Nelson-Hall.

Tuskej, U., Golob, U., \& Podnar, K. (2013). The role of consumer-brand identification in building brand relationships. Journal of Business Research, 66, 53-59.

Underwood, R., Bond, E., \& Baer, R. (2001). Building service brands via social identity: lessons from the sports marketplace. Journal of Marketing Theory and Practice, 9, 1-13. 